\title{
COMPARATIVE STUDY BETWEEN THREE COURTYARDS OF TRADITIONAL HOUSES IN ISLAMIC CAIRO
}

Yehia Hassan Wazeri
Assistant professor- Dept. of Architecture

High Institute of Engineering \& Technology, Al Arish, Egypt.

E-mail: drwazeri@yahoo.com

\begin{abstract}
Direct solar radiation is considered the most important climatic element, which has direct and indirect influences on designing buildings and open spaces. In hot arid regions, like Cairo, the main aim is to reduce the heat load in summer, and to maximize it in winter. The aim of the present comparative study is to determine the shaded area and the quantity of direct solar radiation (on 21 June \& 21 December) fall on walls, floors and openings of three courtyards in traditional Islamic houses in old Cairo. For this purpose a network of three traditional courtyards houses has been selected in old Islamic Cairo. The first is Zaynab Khatun house (built 1468AD), the second is Gamal Al-Din Al-Dahaby (built 1637AD), and the third is Es-Sinnari house (built 1794AD).
\end{abstract}

Key words: courtyards; traditional houses; Islamic Cairo.

\begin{abstract}
Abstrak
Radiasi matahari langsung merupakan elemen iklim yang paling penting untuk dipertimbangkan dalam perancangan, baik yang memberikan pengaruh langsung maupun tidak langsung pada perancangan bangunan dan ruang terbuka. Di daerah kering dan panas, seperti halnya Cairo, beban panas di musim panas dikurangi dan dimaksimalkan di musim dingin. Tujuan dari penelitian yang menggunakan tiga studi banding ini adalah untuk menentukan daerah yang teduh dan melihat jumlah radiasi matahari langsung pada tanggal 21 Juni dan 21 Desember, yang mengenai pada dinding, lantai dan bukaan yang bersumber dari halaman rumah tradisional Islam di kota tua Kairo. Untuk itu, telah dipilih tiga rumah tradisional di Kairo yang memiliki halaman yaitu rumah Zaynab Khatun yang dibangun pada 1468AD, kedua rumah Gamal Al-Din Al-Dahaby yang dibangun pada $1637 A D$, dan yang ketiga adalah rumah Es-Sinnari yang dibangun pada 1794AD.
\end{abstract}

Kata kunci: halaman, rumah-rumah tradisional, Islam Kairo.

\section{Introduction}

Housing is a basic human need. Its primary purpose is to provide shelter from the stresses of the surrounding environment. In addition a house offers comfort and convenience to those living in it. Help towards providing the comfort requires recognizing some general principles of house design in relation to the elements of climate.

Direct solar radiation is considered the most important climatic element, which has direct and indirect influences on designing buildings and open spaces. In hot arid regions, like Cairo, the main aim is to reduce the heat load in summer, and to maximize it in winter.

Courtyard thermal performance is mainly affected by the solar radiation penetration on the internal envelope. The courtyard building form can be an efficient modifier to the climatic conditions if special arrangements are made at the early stages of the building design.

Younes and A.Mohsen investigated four traditional courtyard houses in Cairo. ${ }^{1}$ The temperature of air inside courtyards is lower than the outdoor air temperature in summer. A relation between the cooling effect and the degree of enclosure of the courtyard was established, the produced cooling effect becomes more significant when enclosure increases.

A Comparative study was carried out in eight traditional courtyard houses in Riyadh. ${ }^{2}$ The study concluded that the optimum proportions for the courtyard (width: length) is $1: 1.3$, for courtyard area which not exceed $200 \mathrm{~m}^{2}$.

A Comparative study was carried out in four different cities around the world representing the main four different climates. ${ }^{3}$ These cities are Kuala Lumpur, Cairo, Rome and Stockholm. 
A case study is taken in relation to 28 Damascene courtyards houses. ${ }^{4}$ The study relied on analyzing the Iwan elevation as well as the inner courtyard proportion in relation to the building area.

The aim of the present comparative study is to determine the shaded area and the quantity of direct solar radiation (on 21 June \& 21 December) fall on walls, floors and openings of three courtyards in traditional Islamic houses in old Cairo.

For this purpose a network of three traditional courtyards houses has been selected in old Islamic Cairo from Ottoman period. The first is Zaynab Khatun house(built 1468AD), the second is
Gamal Al-Din Al-Dahaby (built 1637AD), and the third is Es-Sinnari house (built 1794AD).

\section{Courtyards and Equations}

Courtyards orientations and dimensions:

A study of the exposed and shaded area on 21 June (over heated period) and 21 December (under heated period) was carried out in the three courtyards.

The courtyards orientation and dimensions with its details of openings were determined, figure1. The photos and measurements for shaded and exposed areas of the courtyards were taken in some particular hours (on 21 June \& 21 December).
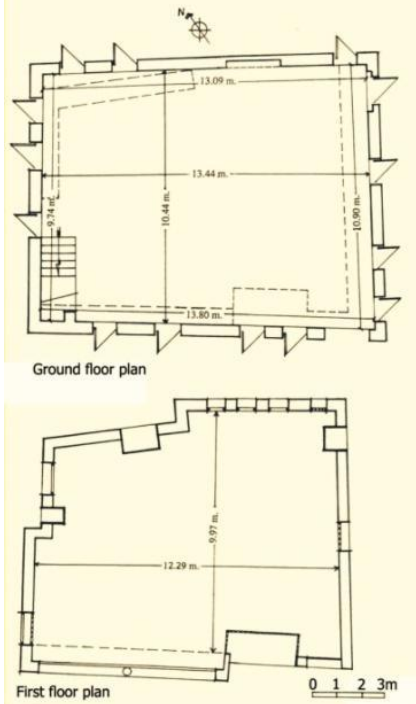

Al-Dahaby courtyard
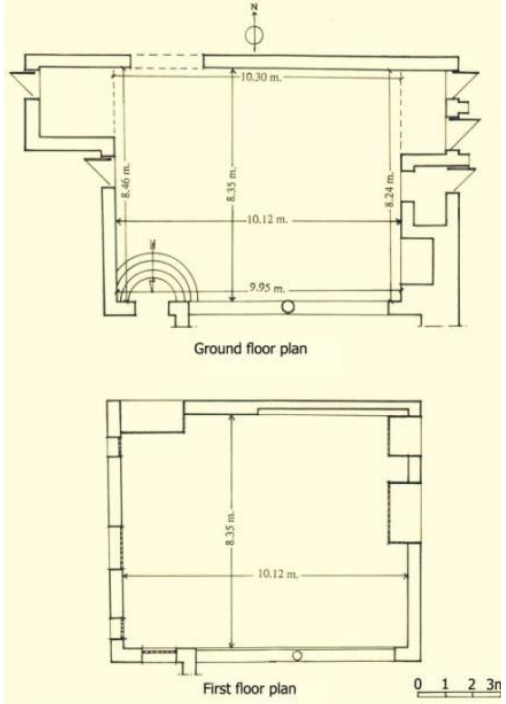

Es-Sinnari courtyard
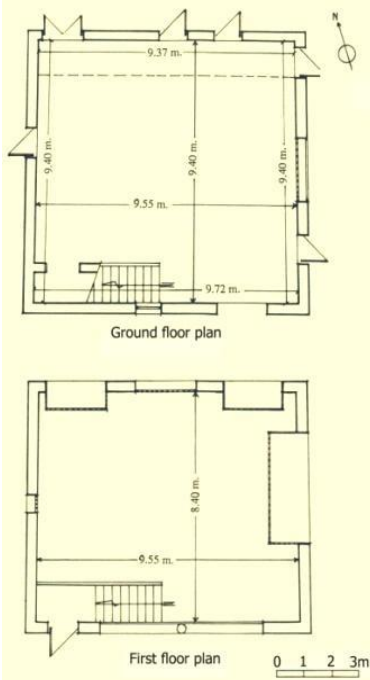

Zaynab Khatun courtyard

Figure 1. The courtyards orientation and dimensions (The researcher)

Geometry equations of the courtyard:

Openness to the sky may be determined from ${ }^{5}$ :

Openness to the sky $=A_{T} / A_{G}$

Where:

$A_{T}=$ Area of the courtyard's top surface.

$A_{G}=$ Area of the courtyard's ground surface.

Enclosure ratio $(\mathrm{R})$ may be determined from ${ }^{6}$ :

$(\mathrm{R})=\mathrm{S} / \mathrm{A}_{\mathrm{T}}$

Where:

$\mathrm{S}=$ Area of the surrounding walls of the courtyards

Determination of horizontal and vertical shadow angles:

The values of azimuth and altitude angles of Cairo $\left(30^{\circ} \mathrm{N}\right.$ latitude) were obtained by using the sunearthtools program.

Values of horizontal shadow angle (HSA) may be obtained from ${ }^{8}$ :
$\mathrm{HAS}=/\left(\mathrm{a}-\mathrm{W}_{\mathrm{A}}\right) /$

Where:

$\mathrm{a}=$ azimuth angle.

$\mathrm{W}_{\mathrm{A}}=$ Wall's orientation.

Values of vertical shadow angle (VSH) may be obtained from ${ }^{9}$ :

$\operatorname{Tan}(\mathrm{VSH})=\operatorname{Tan}(\mathrm{A}) / \operatorname{Cos}(\mathrm{HAS})$

Where:

A = Altitude angle.

Equations for calculating the intensity of direct solar radiation:

The hourly direct normal solar radiation $\left(I_{D N}\right)$ data for Cairo station in Egypt were used. This data was obtained from the official files of the Authority of Meteorology at Kobry El-Koba in Cairo, on 21 June and 21 December. ${ }^{10}$

The amount of direct solar radiation falling on a surface $\left(I_{D}\right)$ is equal to the direct normal solar 
radiation $\left(\mathrm{I}_{\mathrm{DN}}\right)$, corrected for the angle of incidence $(\Theta)$ of the surface ${ }^{11}$ :

$I_{D}=I_{D N} \operatorname{Cos} \theta$ Watt $/ \mathrm{m}^{2}$

If the surface is a wall or other vertical plane, the altitude of incidence is computed as a function of the sun's altitude angle (A) and its bearing angle relative to the wall (b) ${ }^{12}$ :

$\operatorname{Cos} \theta=\operatorname{Cos}(A) \operatorname{Cos}(b)$

$I_{D V}=I_{D N} \operatorname{Cos}(A) \operatorname{Cos}\left(a-W_{A}\right)$ Watt $/ m^{2}$

Where:

$\mathrm{I}_{\mathrm{DV}}=$ The amount of direct solar radiation falling on a vertical surface.

If the surface is a roof or other horizontal surface, the angle of incidence is simply the complement of the altitude angle of the sun ${ }^{13}$ :

$\left(Z=90^{\circ}-A\right)$

Where:

$\mathrm{I}_{D H}=$ The amount of direct solar radiation falling on a horizontal surface.

Results and Discussion

Geometrical description of the investigated courtyards:
The geometries of the investigated courtyards are shown in table 1. From that table, it was found that:

1-There are no projections in the upper floors of Es-Sinnari courtyard facades $\left(A_{T} / A_{G}=1\right)$. In Zaynab Khatun, there is a horizontal projection in the southern façade $\left(A_{T} / A_{G}=0.89\right)$. The largest ratio of projections $\left(\mathrm{A}_{T} / \mathrm{A}_{G}=0.85\right)$ are presented in $\mathrm{Al}$ Dhaby courtyard.

2- Zaynab Khatun courtyard has the largest enclosure ratio $(5.96)$ with the largest average height for the four facades. This explains why sun rays enter the courtyard at 8.00 a.m. on 21 June, while in Al-Dhaby and Es-Sinnari courtyards enter at 6.00 a.m. For the same reason, the sun rays enter Zaynab Khatun courtyard at 9.00 a.m. on 21 December, but in the other two courtyards they enter at 8.00 a.m.

3- The average height of the investigated courtyards does not exceed one and half the width, except for Zaynab Khatun courtyard, where $w: h=1: 1.58$.

4- The proportion between width and length of the investigated courtyards not exceed 1:1.30.

Table 1. Geometries of the investigated courtyards (The researcher)

\begin{tabular}{|c|c|c|c|}
\hline $\begin{array}{r}\text { Name of the } \\
\text { courtyard }\end{array}$ & Zaynab Khatun & Al. Dhaby & Es-Sinnari \\
\hline Orientation & $17^{\circ}$ East - North & $28^{\circ}$ East - North & $0^{\circ}$ \\
\hline $\begin{array}{l}\text { Average dimensions }(W \times \grave{L} \\
x h), m\end{array}$ & $9.40 \times 9.55 \times 13.34$ & $10.44 \times 13.44 \times 12.41$ & $8.35 \times 10.12 \times \times 10.00$ \\
\hline $\begin{array}{l}\text { Area of courtyard's ground } \\
\text { surface }\left(A_{G}\right), m^{2}\end{array}$ & 89.77 & 140.31 & 84.50 \\
\hline $\begin{array}{l}\text { Average dimensions of plan } \\
\text { after projections (WXL),m. }\end{array}$ & $8.40 \times 9.55$ & $9.74 \times 12.29$ & $8.35 \times 10.12$ \\
\hline $\begin{array}{l}\text { Area of courtyard's top } \\
\text { surface }\left(A_{T}\right), m 2\end{array}$ & 80.22 & 119.70 & 84.50 \\
\hline Openness to the sky $\left(\frac{A_{T}}{A_{G}}\right)$ & 0.89 & 0.85 & 1 \\
\hline $\begin{array}{l}\text { Area of surrounding walls } \\
(S), m 2 \text {. }\end{array}$ & 478.90 & 543.40 & 368.66 \\
\hline $\begin{array}{l}\text { Enclosure ratio } \\
\left(R=\frac{\mathrm{S}}{\mathrm{A}_{\mathrm{T}}}\right)\end{array}$ & 5.96 & 4.53 & 4.36 \\
\hline $\begin{array}{l}\text { Proportions of the courtyard } \\
\text { (W:L:h) }\end{array}$ & $1: 1.13: 1.58$ & $1: 1.26: 1.27$ & $1: 1.21: 1.19$ \\
\hline
\end{tabular}

\section{Shaded area ratio of the investigated courtyard}

The calculations of the shaded area showed that the ground surface of Zaynab Khatun courtyard is over $82 \%$ shaded and over $77 \%$ of its facades are shaded in summer (21 June). While AlDhaby and Es-Sinnari courtyards show lesser 
values, $75 \%, 81 \%$ and $74 \%, 72 \%$ respectively. A relation between the increasing of shaded surfaces and the degree of enclosure of the courtyards was established.

In winter (21 December), the ground surfaces and north facades are $100 \%$ shaded, but the other facades are over $83 \%$ shaded of Zaynab Khatun, over $81 \%$ of Es-Sinnari and over $79 \%$ of Al-Dhaby.

\section{Amount of solar radiation received by courtyards} surfaces

On 21 June, It was observed that the ground surface of the three courtyards receive the largest amount of solar radiation at 12.00 a.m. In Zaynab Khatun and Al-Dhaby courtyards, the west facades receive the largest amount at 15.00 p.m., while the east facade of Es-Sinnari receives the largest amount at 9.00 p.m. and the west façade at 15.00 p.m., figure 2 .

On 21 December, the south façade of Zaynab Khatun and Es-Sinnari courtyards receive the largest amount of solar radiation at 12.00 a.m, while in Al-Dhaby courtyard at 14.00 p.m., figure 2.

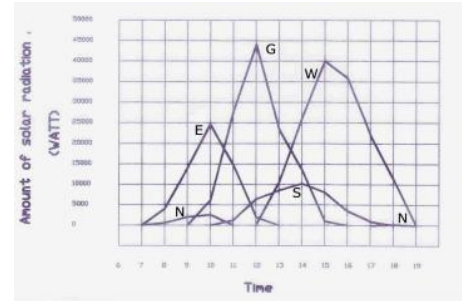

On 21 June

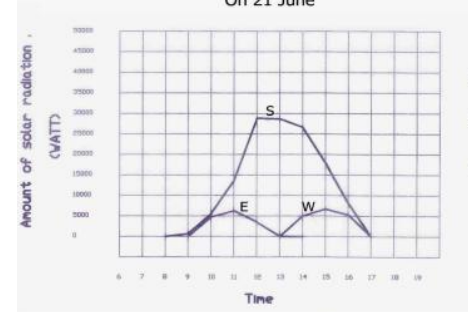

On 21 December

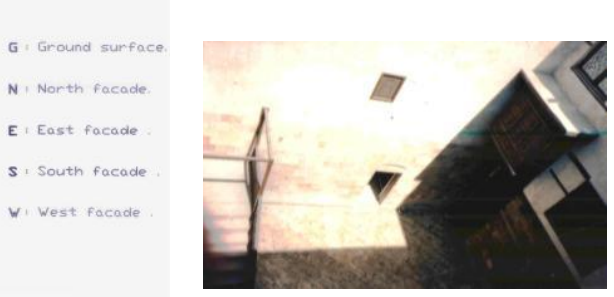

10 am., on 21 June

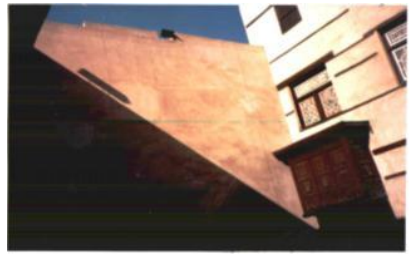

12 a.m., on 21 December

Figure 2a. Curves of solar radiation amount received by Zaynab Khatun courtyard surfaces on 21 June and 21 December and some photos in particular time (The researcher)

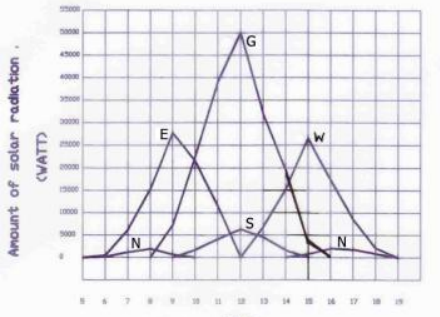

On 21 June

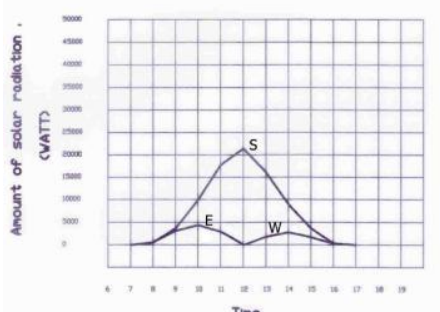

On 21 December
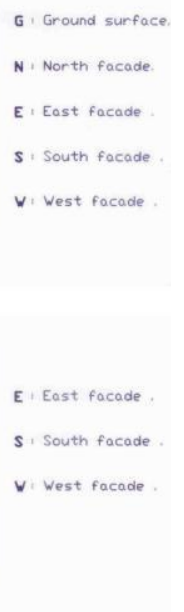

14 p.m., on 21 December

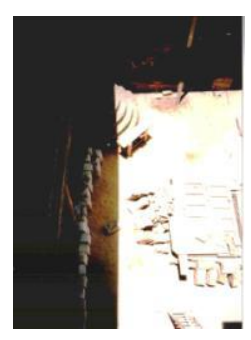

12 a.m., 21 June

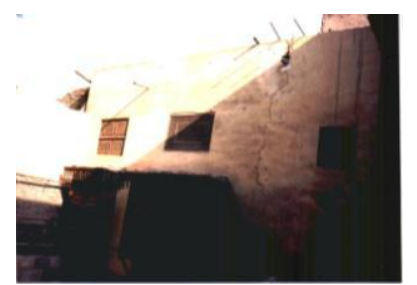

Figure 2b: Curves of solar radiation amount received by Es-Sinnari courtyard surfaces on 21 June and 21 December and some photos in particular time (The researcher) 

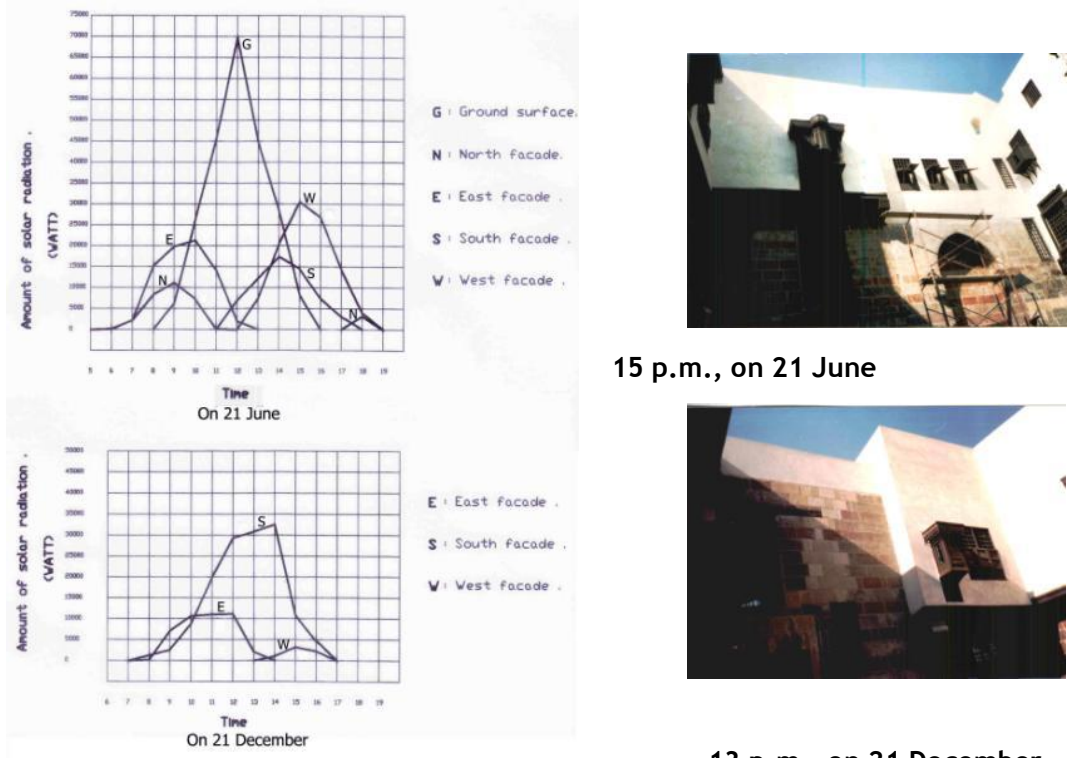

15 p.m., on 21 June

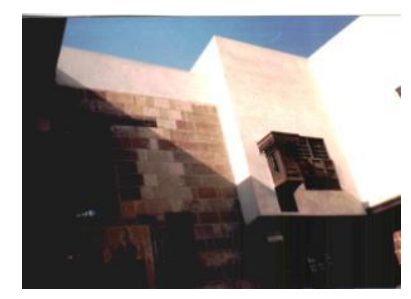

13 p.m., on 21 December

Figure 2c. Curves of solar radiation amount received by Al-Dhaby courtyard Surfaces on 21 June and 21 December and some photos in particular time (The researcher)

Because the investigated courtyards differ in size and orientation, the amount of solar radiation per unit area was used to compare them. From table 2, the following was observed:

- On 21 June, the ground surface of Zaynab Khatun courtyard receives the smallest amount of solar radiation and the ground surface of Es-Sinnari courtyard receives the largest amount. The facades of Al-Dhaby courtyard receive the smallest amount of solar radiation, because they have the largest ratio of projections when compared with the other two courtyards. Es-Sinnari facades receive the largest amount of solar radiation because they did not have any projections.

- On 21 December, Al-Dhaby courtyard receives the largest amount of solar radiation.

- Taking in the consideration the total amount of solar radiation received by ground surface and the facades together (without North façade), it was found that Zaynab Khatun courtyard receives the smallest amount.

Because the north facades of the three courtyards receives the smallest amount of solar radiation on 21 June, the summer "Meka'ad" (open reception men space in the first floor) and "Al Taktabosh" (open reception men space in the ground floor) are located in this façade.
Table 2. Average amount of solar radiation per unit area received by the courtyards surfaces on 21 June and 21 December (The researcher)

\begin{tabular}{|c|c|c|c|c|c|}
\hline $\begin{array}{r}\text { Courtyard's } \\
\text { name }\end{array}$ & Zaynab Khatun & Al-Dhaby & Es-Sinnari \\
Comements
\end{tabular}

Amount of solar radiation received by courtyards openings

It was observed that the north facades of the courtyards have the largest area of openings. The ratio of openings is $33 \%$ in Zaynab Khatun courtyard, $69.71 \%$ in Al-Dhaby courtyard and 
$55.50 \%$ in Es-Sinnari courtyard. The shaded and exposed area and openings of the north facades on 21 June are shown in figure 3.

The ratio of openings of east facades is $2.82 \%$ in Zaynab Khatun courtyard, $16.51 \%$ in AlDhaby courtyard and $18 \%$ in Es-Sinnari courtyard. The shaded and exposed area and openings of the east facades on 21 June are shown in figure 4.

The ratio of openings of south facades is $22.28 \%$ in Zaynab Khatun courtyard, $11.66 \%$ in Al-
Dhaby courtyard and $16.92 \%$ in Es-Sinnari courtyard. The shaded and exposed area and openings of the south facades on 21 June are shown in figure 5 .

The ratio of openings of west facades is $20 \%$ in Zaynab Khatun courtyard, $18 \%$ in Al-Dhaby courtyard and $23.34 \%$ in Es-Sinnari courtyard. The shaded and exposed area and openings of the west facades on 21 June are shown in figure 6.
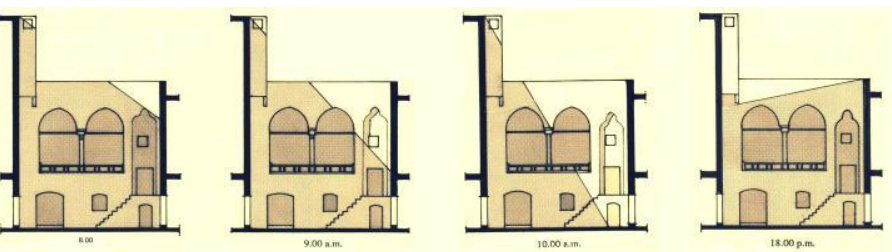

The north facade of Zaynab Khatun courtyard
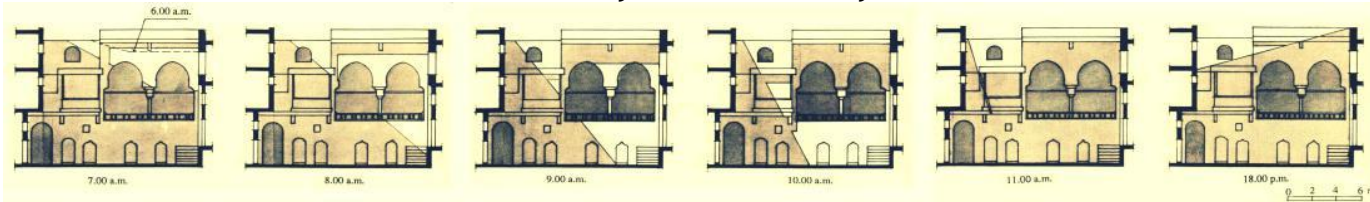

The north facade of Al-Dhaby courtyard

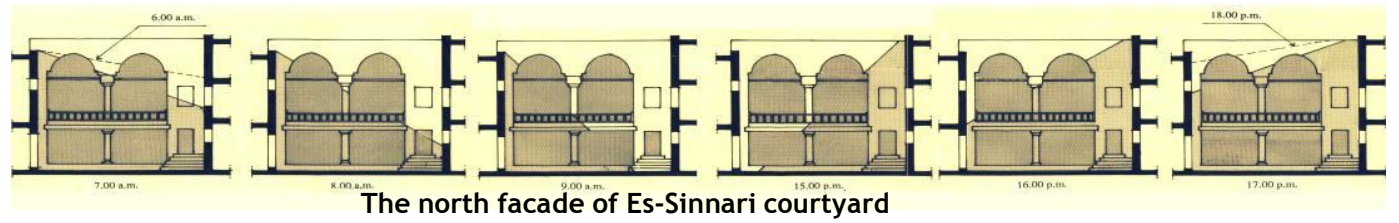

Figure 3. The shaded and exposed area and openings of the north facades on 21 June (The researcher)
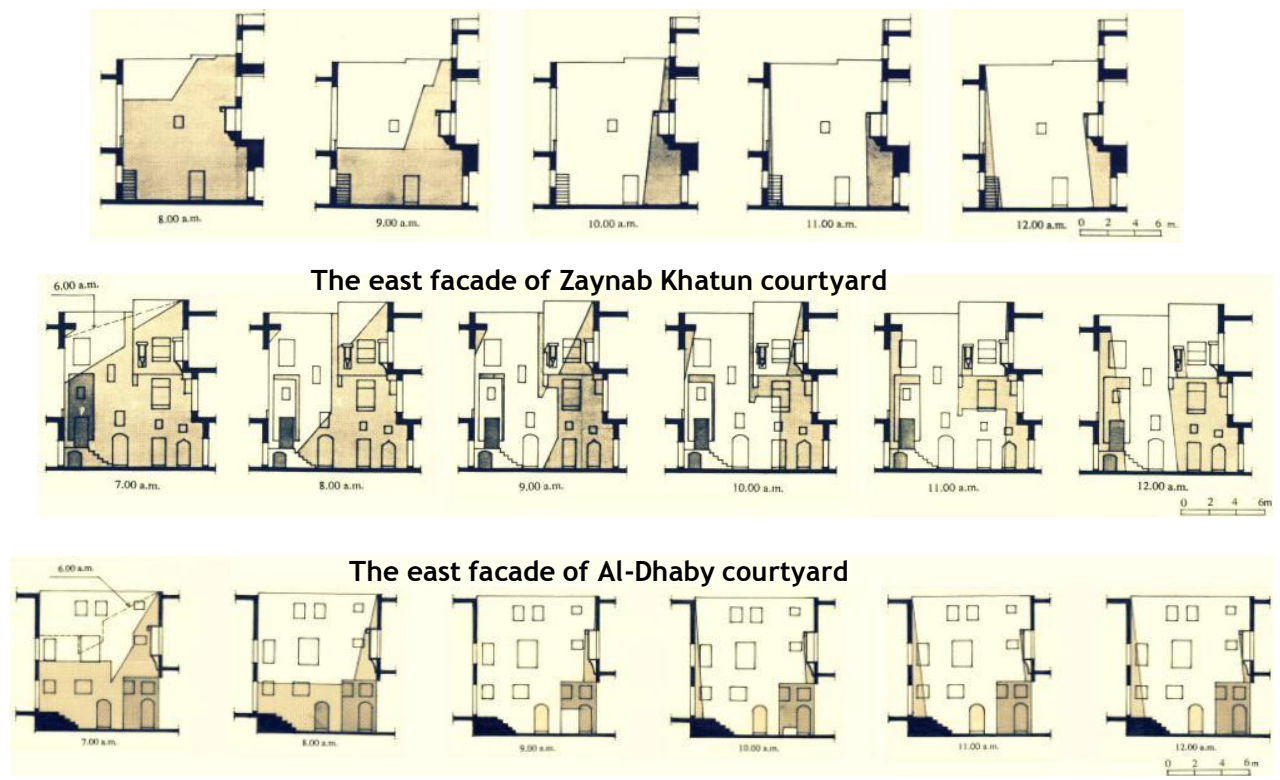

The east facade of Es-Sinnari courtyard

Figure 4. The shaded and exposed area and openings of the east facades on 21 June (The researcher) 


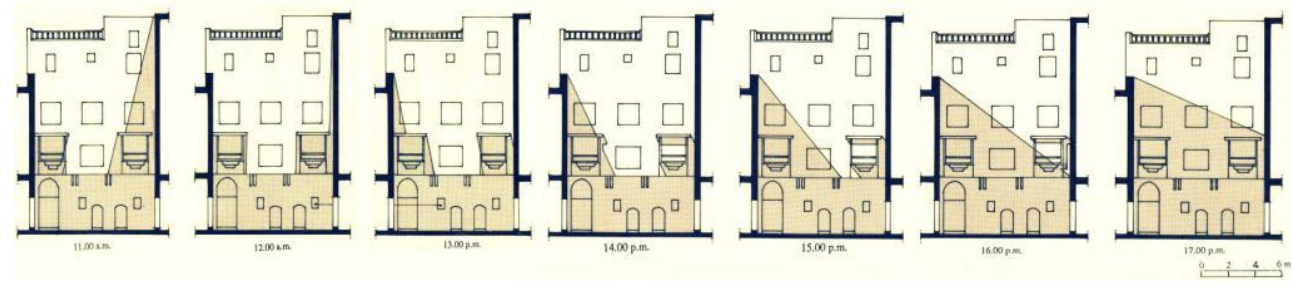

The south facade of Zaynab Khatun courtyard
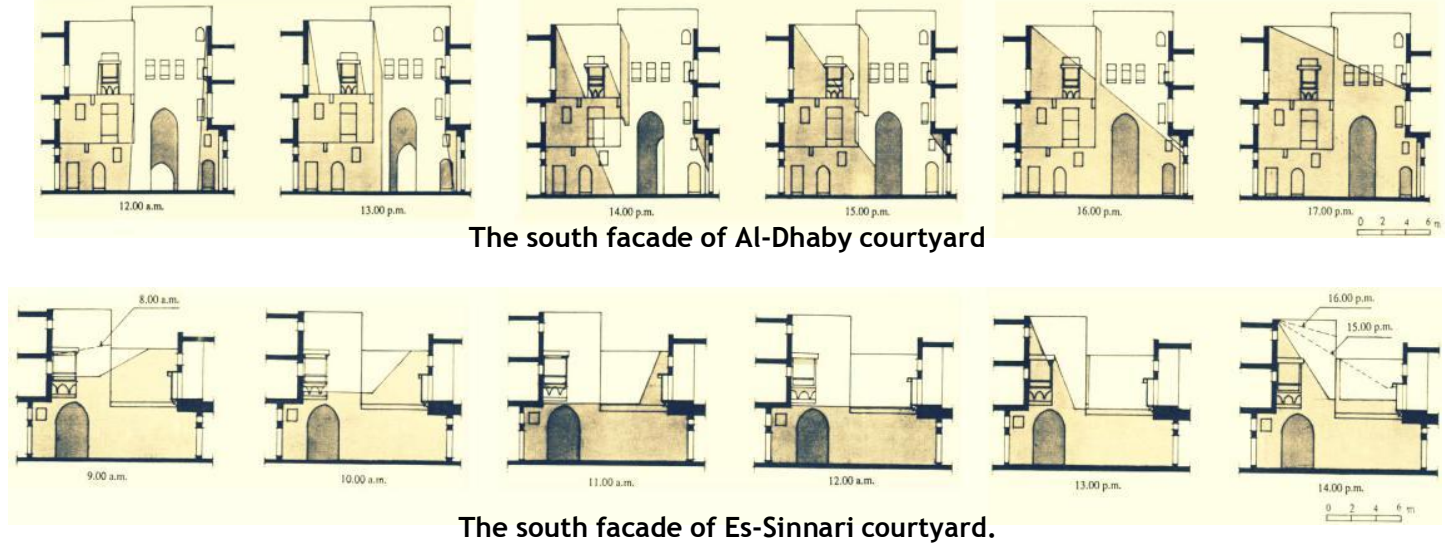

Figure 5. The shaded and exposed area and openings of the south facades on 21 June (The researcher)
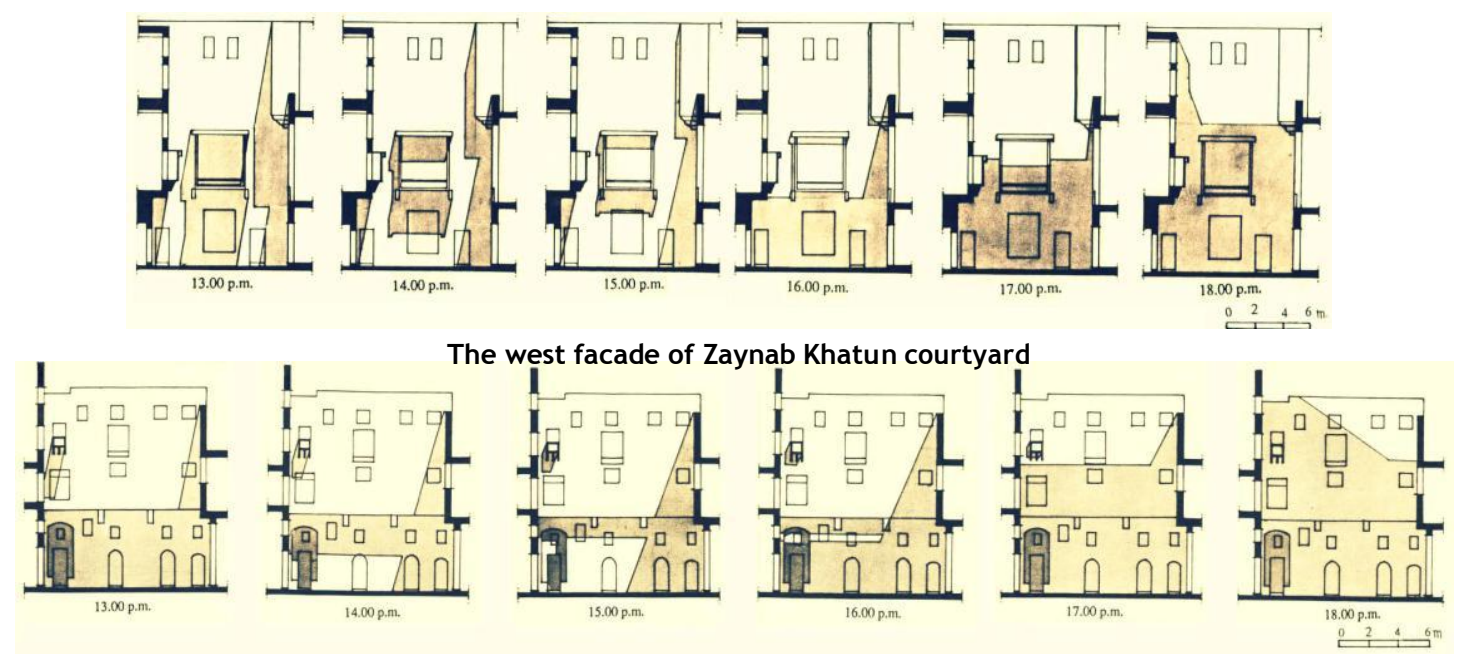

The west facade of Al-Dhaby courtyard

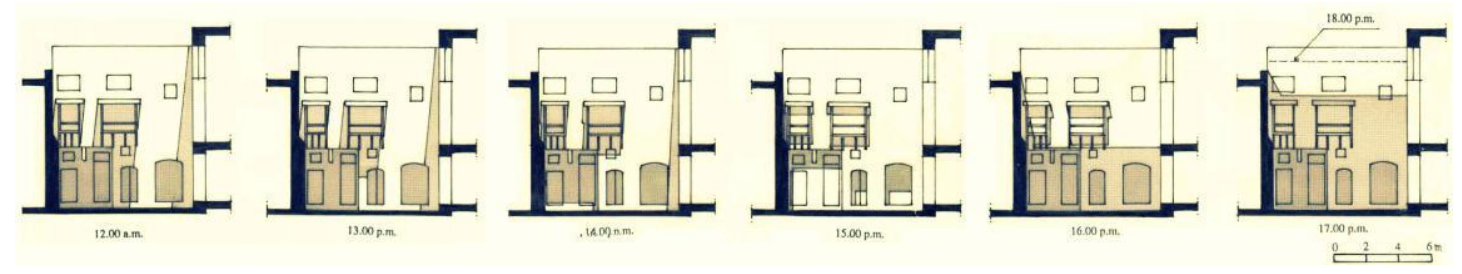

The west facade of Es-Sinnari courtyard

Figure 6. The shaded and exposed area and openings of the west facades on 21 June (The researcher) 
The amount of solar radiation received by courtyards openings (on 21 June and 21 December) is represented in figure 7 .

It was found that the openings of west façade of Zaynab Khatun and Al-Dhaby courtyards receive the largest amount of solar radiation, where the openings of the east façade of Es-Sinnari courtyard receive the largest amount on 21 June (summer).

On 21 December, the openings of south façade of the three courtyards receive the largest amount of solar radiation.

When comparing the average amounts of solar radiation per unit area of openings received by the courtyards, table 3 , it was found that the openings of Es-Sinnari and Zaynab Khatun courtyards receive the smallest amount on 21 June (summer). Where the openings of Al-Dhaby courtyard receive the largest amount of solar radiation on 21 June and 21 December.

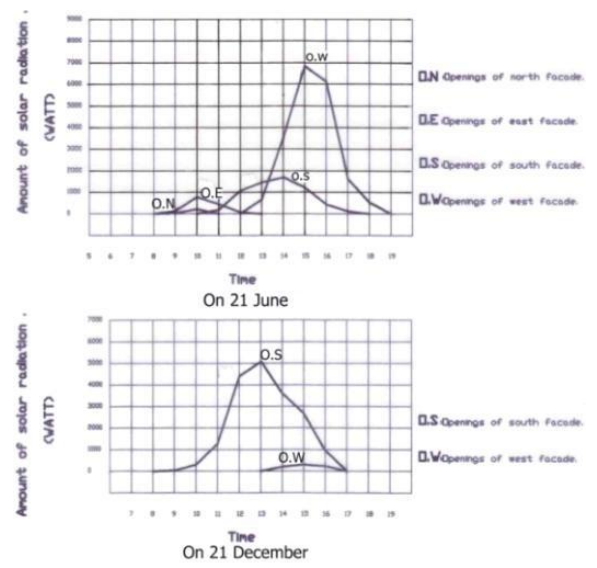

Figure 7a: Curves of solar radiation amount received by Zaynab Khatun courtyard openings on 21 June and 21 December (The researcher)

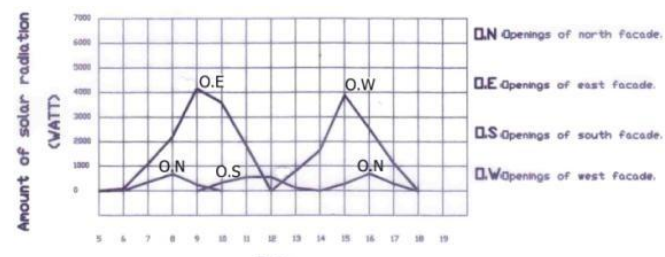

On 21 June

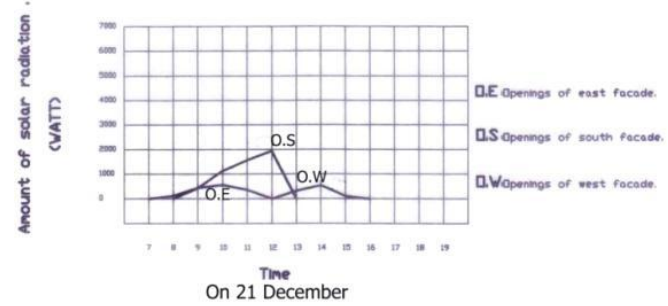

Figure 7b. Curves of solar radiation amount received by Al-Dhaby courtyard openings on 21 June and 21 December (The researcher)

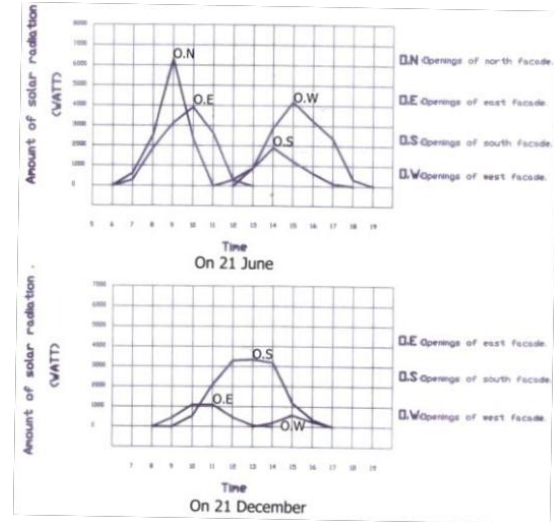

Figure 7c. Curves of solar radiation amount received by Es-Sinnari courtyard openings on 21 June and 21 December (Theresearcher).

Table 3. Average amount of solar radiation per unit area received by the courtyards openings on 21 June and 21 December (The researcher)

\begin{tabular}{|c|c|c|c|c|c|c|}
\hline $\begin{array}{r}\text { Courtyard's } \\
\text { name }\end{array}$ & \multicolumn{2}{l|}{ Zaynab Khatun } & \multicolumn{2}{l|}{ Al-Dhaby } & \multicolumn{2}{l|}{ Es-Sinnari } \\
\begin{tabular}{|c|c|c|c|c|c|c|} 
Comparetive \\
elements
\end{tabular} & & & & & \\
\hline $\begin{array}{l}\text { Average amount of solar } \\
\text { radiation per unit area of } \\
\text { openings (watt) }\end{array}$ & 21 June & 21 Dec. & 21 June & 21 Dec. & 21 June & 21 Dec. \\
\hline North facade & 8.17 & 0.00 & 108.99 & 0.00 & 48.18 & 0.00 \\
\hline East facade & 548.47 & 0.00 & 607.68 & 162.19 & 806.77 & 93.84 \\
\hline South facade & 195.40 & 578.18 & 263.92 & 725.67 & 101.60 & 318.70 \\
\hline West facade & 720.10 & 28.26 & 653.19 & 48.91 & 551.12 & 70.55 \\
\hline (East+South+West) & 1463.97 & 606.44 & 1524.79 & 963.77 & 1459.66 & 483.09 \\
\hline Total & 1472.14 & 606.44 & 1693.78 & 963.77 & 1507.67 & 483.09 \\
\hline
\end{tabular}

\section{Conclusion}

A study of the exposed and shaded surfaces and openings on 21 June (over heated period) and on 21 December (under heated period) was carried out in three courtyards in old Islamic Cairo from Ottoman period.

The enclosure ratio and the facades projections have a significant effect on increasing the shaded surfaces. So, the ground surface of Zaynab Khatun courtyard receives the smallest amount of solar radiation on 21 June, because it has the largest enclosure ratio. The facades of Al-Dhaby courtyard receive the smallest amount of solar radiation, because they have the largest ratio of projections. 
The average height of the investigated courtyards does not exceed one and half the width, except for Zaynab Khatun courtyard, where $w: h=1$ : 1.58. Increasing the walls height of Zaynab Khatun courtyard, delaying the sun rays from entering the courtyard from 1-2 hours, in both summer and winter, when comparing with the two other courtyards.

It was observed that each facade of the investigated courtyards has its own design, and openings ratio and arrangement with respect to solar radiation. Because the north facades of the three courtyards receive the smallest amount of solar radiation on 21 June, the north facades of the courtyards have the largest area of openings. The summer "Meka'ad" (open reception men space in the first floor) and "Al Taktabosh" (open reception men space in the ground floor) are located in this façade.

In applying the results, one can design a new courtyard house with reference to the geometrical relationships and facades projections and openings discovered in the traditional courtyard houses without copying it.

\section{References}

1 A. Younes. and M.A. A.Mohsen. 1980. The courtyard as $\mathrm{s}$ passive solar design means in buildings. The international congress on solar energy, Istanbul

2 M. Al Hussayen. 1995. Significant characteristics and design considerations of the courtyard house. Journal of Architectural and planning research, Chicago, vol. 12 , No. 2
3 A. Muhaisen. 2006. Shading simulation of the courtyard form in different climatic regions. Building and Environment 41 (2006) 1731-1741

4 S. Ferwati and A. Mandour .2008. Proportions and human scale in Damascene courtyard houses. International Journal of Architectural Research, Vol. 2 - No. 1 (247-263) (Available in: http://archnet.org/library/documents/onedocument.jsp?document_id=10334 (Accessed October 15, 2012))

5 M.A. A.Mohsen. 1978. The thermal performance of courtyard houses (Ph.D. Thesis). Department of Architecture, University of Edinburgh

6 Ibid

7 http://www.sunearthtools.com(Accessed October10, 2012)

8 M.T. El-Mehelmy. 1990. Evaluation and prediction of the performance of some passive solar systems and heat gain control on building envelope, using a computer model (M.Sc.Thesis). Faculty of Engineering, Department of Architecture, Cairo University.(In Arabic)

9 Ibid

10 Y.Wazeri, 1997. The relationship between solar radiation and building design in North Africa (M.Sc.Thesis). Institute of African research and studies, Department of Natural resources, Cairo University

11 Ibid

12 Ibid

13 Ibid 